\title{
Reconstructing Identity through Voyages in/ out in Toni Morrison's God Help the Child: A Psychogeographical Analysis
}

\author{
Hana Bougherira \\ Department of Foreign Languages \\ Skikda University, Algeria
}

\begin{abstract}
People's voyages to different geographies may have diverse purposes. While some are just flâneurs taking routes aimlessly, others are stalkers with a preliminary idea about the significance of their derives. Aimless or not, the different geographies visited inevitably shape and reshape the walker's character and psyche. This article analyzes Morrison's latest novel, God Help the Child (2015), in the prism of the theory of psychogeography, which studies the correlative relation between psyche and geography. The article posits the question how does the novel's protagonist, Bride, grows from a flâneur to a stalker in the light of the degrading capitalist American society and how do the different voyages out initiate her to some metaphorical voyages in, enabling her to reconstruct her identity as a black female and a future black mother. Bride's wonderings about her identity, erased by a character called Booker, lead her to wandering to different territories (Decagon, the countryside and whisky) each of which dictates on her new ideologies and ethics, which, in turn, alter her behavior and outlook. The article evetually elucidates how the final station in Bride's journey is a cathartic one through which she reclaims her freedom, recovers her identity and empowers herself and the black community.
\end{abstract}

Keywords: female identity, God Help the Child, psychogeography, Toni Morrison, voyage in/ out,

Cite as: Bougherira, H. .(2020). Reconstructing Identity through Voyages in/ out in Toni Morrison's God Help the Child: A Psychogeographical Analysis. Arab World English Journal for Translation \& Literary Studies 4 (2) 263-275.

DOI: http://dx.doi.org/10.24093/awejtls/vol4no2.20 


\section{Introduction}

No black literary work can be read and fully understood without contextualizing it within what is called Black Experience; a two-word expression that ironically needs a million words to tell about. Briefly, it has to do with a long, horrific and forced voyage of slaves from the mother continent Africa, across the Atlantic, to the Americas where they become not merely dehumanized but also socially marginalized, economically oppressed, psychologically traumatized and culturally and linguistically dispossessed. It has been said that what proves the humanity of a race is its literature; Toni Morrison is one of the authors who could successfully validate that, enriching the blacks' literary heritage. She excels at what came to be known as writing glocal, a significant contrapuntal fusion between the local and the global, that aims at upgrading the blacks' struggle to a larger post-colonial movement preventing it from dissolving into a mere existential rebellion. Morrison's careful and critical re-assessment of the very fabric of the black community, especially what it means to be a black female in the United States, and her daring engagement with the voicing of all the lacunas in history and literature makes her a well appreciated author whose literature appealed and still appeal to a worldwide audience.

Morrison's latest novel, God Help the Child (2015), is simply the story of black female's sustained movement from victimhood into victorhood in a merciless, racist and unforgiving community. She recounts the story of Bride, who is othered by so many because of her color. Morrison's novel is set in a postmodern capitalist American society and culture that poses many challenges. While it has opened many doors of acceptance and plurality, it has put some pressure on others. The requirements of a postmodern age can be very stressful and high in rhythm that not everyone can easily cope with them. Prison-like lifestyle that traps people in an infinite cycle of routine. Running continuously to cope with its exigencies can relatively culminate in psychological malaise, identity crisis, divorce and escape just to name a few. The oppressive capitalist system has always been part of a conspiracy that entrapped people in a widening gyre of an everlasting sense of alienation and materialism. Starting from modernity up to the post-postmodern times, people wake up to pursue the needs of world of objects. Such a tempting lifestyle generally results in a number of psychologically troubled individuals who are torn between what they actually need and what they should have. Consequently, those who fail to decipher the riddle can fall in a furnace of constant doubts while those who are awakened to the urge of resistance can succeed in overcoming it, each in their specific, personal ways. Travel is one of the countless means of such resistance that has been the groundwork for so many theorists who could develop their own theories on it. Psychogeography is one of the fields that could study the influence of places, spaces and new geographies on the psyches of the individuals. This article approaches the selected novel of Morrison, God Help the Child, using the theory of psychogeography. It first sheds light on the conceptual/theoretical framework of what is meant by psycho-geography and the main elements that concern this analysis. Second, it reviews the body of literature written on Morrison's novel to identify the gap in the literary discussion highlighting the significance of this study. The latter lies in the fact that the reading of this novel from a psychogeographical perspective has meagerly been treated before. It moves to read Bride's experience through the lens of these elements, demonstrating how she grows to be a postmodern female stalker who could successfully reconstruct her identity through a number of physical and metaphorical voyages.

Arab World English Journal for Translation \& Literary Studies 


\section{Psychogeography Approach}

As its name implies, psychogeography can be defined as the marriage between the two fields of psychology and geography, which brings about a new space that studies the impact of geography on the human psyche. As a concept, it owes origin to the early nineteenth century British and French novelists and to the early writings of Guy Debord. The latter defines the term as, "the study of the specific effects of the geographical environment, consciously organized or not, on the emotions and the behavior of individuals"i (as cited in Muis, 2015, p. 2). Debord's definition emphasizes the essence of psychogeography, which lies in the effect of a being in or to a place intentionally or unintentionally chosen. Coverley (2018) defines it rather as, "the point at which psychology and geography collide, as a means of exploring the behavioral impact of an urban space" (p. 10). Contemporary psychogeographers could bring the term to the surface again adding more elements and deeper explanations of what the concept implies. In her article entitled "Walking Inside out", Richardson (2015) actually finds that psychogeography does not have to be complicated, "anyone can do it, you do not need a map, Gore Tex, rucksack or companion, all you need is a curious nature and comfortable pair of shoes" (p.1). Richardson's definition is so simple that it reduces the essence of psychogeography to a mere planned journey. The latter should entail more than a depiction; it has to bring forth a sense of criticism that can be constructive. Believing that psychological conditions can inevitably be provoked by certain places and that every location has its own personality that it dictates on individuals, psychogeographers become more than simple passengers. Their mission of creating both geographical and psychological maps can be empowering and transformative at the same time. What is worth noting, however, is the relativity of the impact of the diverse places on the different individuals. In other words, while some places can be a site of growth and change for some, for some others they are the source of all chaos. Accordingly, the task of psychogeographer is not an aimless one. In the same vein, Richardson gives another dimension to the concept giving it more inclusivity. Richardson (2015) argues that, "psychogeography is about crossing established boundaries, whether metaphorically or physically, locally or globally" (p. 2). Richardson's argument broadens the scope of what a psychogeographer can be and minimizes the simplicity of the first definition. Abdelatif Khatib (2015) describes the dérive, "at the same time as being a form of action, it is a means of knowledge" (as cited in Richardson, 2015, p. 2). Since the concept and the theory of psychogeography resists an accurate definition, Richardson (2015) maintains that she encourages readers to "define their own form of psychogeography or use one of the many definitions [...] to debate the merits of psychogeography and how we might put it to use in the twenty-first century (p.6).

Sinclair (2015), one of the names who could contribute to the conception of psychogeography, sheds light on the significance of the stalker. In his own terms, "the "concept of 'strolling', aimless urban wandering, the flâneur, had been superceded (p. 149). He adds, "we had moved into the age of the stalker; journeys made with intent'. Stalking the city meant 'walking with a thesis' and with 'a prey"' (p. 149). The stalker is more of a reporter and an examiner of the walking space. The terrain under exploration turns to be a site of investigation, information, and sometimes of resistance to the stalker. Likewise, Stein (1989) comments on the strong relation between geography and the psychological impact that it may imprint on the stalker explaining how humans are actually "maps" of their own environment which means that their drifting here and 
there cannot be considered as random or insignificant in any sense. For stein, individuals' psychology is an inevitable site of geographical manifestation. Stein sheds light on other significant elements of psycho-geography like the factors that may influence the walk: time of the day, weather and socio-economic structure just to name a few. He argues, "These features of the walk change the subjective nature of the walk in the same way the intentions of the individual walker do" (p.4). Worth noting, the stalker does not necessary become one just when he takes physical dislocations. In other words, just deciding to transcend boundaries even metaphorically transforms the flâneur to a stalker.

\section{Morrison's God Help the Child: A Review}

Before its publication, a worldwide audience has been eagerly waiting for Morrison's latest novel speculating about the themes, which may concern such a prolific writer with a very distinguished literary heritage. God Help the Child, though at first sight might be considered as a novel on racism and child molestation, is a healing story that calls for transcending a number of crisscross traumas and celebrating the black agency. It is the kind of novel "where you can feel the magnificence just beyond your reach. The writing and storytelling are utterly compelling, but so much is frustratingly flawed. The story carries the shape of a far grander book" (Gay, 2015). The novel has been a subject of an array of schools of thought and literary analysis. So many critics could decipher the multiple significations of the text. One of the early themes that could get a great deal of attention is the theme of motherhood and, particularly, the role of the black mother.

In "What you do to Children Matters": Toxic Motherhood in Toni Morrison's God Help the Child", Manuela López Ramirez (2015) explores the theme of motherhood in the light of its conception in Morrison's previous novels. Ramirez explains how Morrison tends to develop positive mother characters and always tries to shed light on their role as a nurturer and a bearer of culture. Ramirez considers Morrison's model of mother as a site of power and resistance in the sense that she is the one responsible for transmitting positivity, pride and love of the black race in order to be able to challenge and stand against the racist, sometimes sexist, discourse. In other words, the black mother for Morrison is the power that teaches all of her offspring how to be empowered. In God Help the Child, however, Ramirez (2015) finds that Morrison treats motherhood as a dysfunctional institution that disempowers children and fills them with uncertainties and fears. She elucidates, "In God Help the Child, Sweetness' family is an example of matrilineal transmission of racist ideologies and attitudes due to the rupture in the [motherline]" (p. 4). Being tormented by racism and sick of a whole ancestry of unfaithful foremothers to their black race, Sweetness, injects her dissatisfaction and malaise of her own skin in her baby daughter who is few shades darker. Instead of embracing her, Sweetness sets her apart, mercilessly, as an outcast; a stranger at home. Ramirez further stresses that Sweetness follows a genre of motherhood that only seeks absolute and uncontested obedience. She does not foster an affirmative racial identity in her daughter so she can resist racist practices, conversely, she imposes on her the cultural norms, values and expectations of the dominant white culture.

In The Impact of Maternal Influence in Toni Morrison's God Help the Child, Johnsi (2018) claims that,

Arab World English Journal for Translation \& Literary Studies 
Mothers are like roots to a tree; their contribution to the growth of the tree is never seen on the surface but without the deep penetration of the roots and its aid to the tree, the tree will be soon lifeless. (p. 86)

Such an analogy actually negates the fact that children grow different to their mothers. The latter are the early sources of self-love and self-acceptance. Bride falls in the trap of lying just to be accepted by her mother, to realize later that is not the way; that should not be the aim. A mother should not wait for the best conditions to raise her children, she just has to create them. In God Help the Child, Morrison presents mother Sweetness as "sick guilt-ridden woman in a nursing home. She wants to believe that she had raised her daughter right to cope with the harsh reality black people had to face and states "I wasn't a bad mother" (2018, p. 43). Therefore, Morrison does not build an image of a mother to be avoided and not a role model.

Child abuse is one of the other concerns seriously treated by researchers and scholars, as the novel is replete with instances of violence, carelessness, molestation and racism against innocent children whose stories differ but their pain is the same. In "Childhood Cuts Festered and Never Scabbed Over": Child Abuse in Toni Morrison's God Help the Child”, Ramirez (2016) discusses the idea of violence and its impact on the characters. For her, violence as "secondary" or "witness" can have similar effects on the characters' psyche. Morrison's two major characters, Bride and Booker, are both traumatized by child-abuse; witnessed by Bride with her racist mother and just lived as secondary one by Booker's experience of his brother's death, Adam. Despite the fact that both of them grow with a trauma of what they have been through, they end up facing their past and eventually embracing it. Ramirez (2016) reads this as Morrison's focus on the need to put down the traumatic past, and the need of self-forgiveness and self-acceptance; Morrison's story entails a sense of hope that "despite the deep-rooted damage inflicted by child abuse, black individuals can overcome it and live the present fully and intensely" (p. 19).

Racism, the backbone of the novel, is the most outstanding theme in the novel which has been addressed in terms of whiteness and blackness alike. Morrison depicts the predicament of a black community consumed by shadism. The problem is no longer with inter racism but with intra racism. Sad but true, Morrison gives more attention to the racism within the black community itself. In this context, Bougherira (2017) argues,

The dream of the younger generations of blacks is a more serious one than that of Martin Luther King Jr. The new dream confines to the black community in which the black individual has become as oppressive as the white one. To be marginalized by one's own community and to become a stranger at home is more dangerous than being oppressed by an external force. (p. 143)

Morrison sheds light racism but not in the sense that it a hindrance that prevents blacks from enjoying full citizenship, as she offers instances where blackness is no longer an excuse for failure. That is why she opts for a black woman who capitalizes on her beauty to be a financially independent woman. In this context, Myra (2018) contends, "She refuses to surrender to the society 
and so the society accepts her the way she is" (p. 5). The first to reject Bride is the black community itself. That is why Morrison gets her protagonist equipped to defy the assumptions of the blacks themselves. In "Toni Morrison and the New Black Reading God Help the Child”, Akhtar (2018) explains,

It is befitting that Bride is born and raised in the nineties. She comes of age in the twilight of a new black era marked by unprecedented black success in all walks of life, especially in the wake of the polarizing era of post-black and post-racial discourses, a period marked by the rise of the new black celebrity culture. (p. 3)

What can be deduced from the quote above is that the American society has transcended the issue of race and blackness and the proof of that are the countless blacks who have grown to be icons of success and independence. However, even by being a new black and accepted within the larger white culture, blacks still fight their first enemy; their own black community. Furthermore, The dilemma of the new black is that black is always suspect to be old or new. Akhtar (2018) finds that Post-blackness perpetuates blackness. In other words, post-blackness entails more division among the blacks themselves. In God help the Child, however, Bride can be regarded as a new black but with another level of consciousness. A consciousness that rather pushes the limits of defined concepts giving the blacks a more flexible identity or definition that matches best with their socioeconomic status of the twenty first century.

In "A Dissolution of Borderlines in Toni Morrison's God Help the Child”, Brannya (2017) contends that the novel resists any classification and its thematic concerns cannot be confined to one discourse, theme or feature. She finds that Morrison blurs all the boundaries technically and thematically. In other words, the novel discloses a holistic view that mocks the sense of fragmentation that human life, ethics, rules, have. Midst all the chaos and uncertainty, Morrison hits the nails on the head with an all-inclusive novel despite its apparent simplicity. Morrison's novel was and is going to be a subject of literary debates, which this article joins with a psychogeographical approach; a fresh perspective uncovered before.

\section{Discussion: The Figure of the Flâneur in Toni Morrison's God Help the Child}

In Fiction, the plot reveals to the reader something about the kind of movement that goes on. In other words, it discloses whether a movement that has a definite goal by moving from one place to another or not. That is why the geographical movement of the characters in a narrative are so crucial and have to be given more attention in examination and literature. According to the theory of psychogeography, the striking difference between a flâneur and a stalker lies in the fact that whether the dérive taken as an aimless temptation or a well-planned, intentional one. In God help the child, Bride travels to different geographies and new territories that could affect her psychological state in many ways. Her dislocations are all sources of knowledge/self-discovery, critique, and empowerment. In "Post What? Disarticulating Post-Discourses in Toni Morrison's God Help the Child”, Gras (2016) claims that “[Bride]'s geographical travels encourage her to initiate a mental retrospection to realize how she has always been looking for love and appreciation

Arab World English Journal for Translation \& Literary Studies 
in a world where being a Black little girl meant having no value" (p. 10). The early routes that Bride takes lead her gradually to a life changing pavement.

The first destination that Bride heads to is Decagon. Despite the fact that the visit to Decagon is planned and intentional, it does not give Bride an immediate recovery. She subsequently gets more regretful, more lost, and so unsure, wondering why Sofia could not accept her help. However, Sofia considers the visit as a fruitful one as it allows the two women to have a sense of closure. In Sofia's mind, the way she has exercised violence on Bride heals her and puts Bride together. So, in decagon, an aspect of Bride's life is unexpectedly fixed, a lesson is unconsciously learnt.

The mess in Bride's life at this level pushes her to pursue a pressing need to fix her life problems. After Decagon, Bride is still restless and she wants to be a flâneur. In her own terms, she speaks up her wish to her friend Brooklyn saying, "I want a vacation, to go somewhere. On a cruise ship" (Morrison, 2015, p. 45). Bride's initial desire to go on a trip is an escapist attempt to overcome her hammering pain. She does not know where to go exactly nor what she wants out of such a travel. She is tormented and her dreams are bruised that is why her desire is an aimless one. A letter to Booker breaks her escapism and gets her committed to a cause. At the beginning of the course of events, her actions and reactions reveal a docile character who does not show any sense of rebellion. The moment she tries to challenge herself and stops being a passive agent, she becomes a stalker. Bride becomes a rebel who does not accept to be silence or erased because Booker deliberately silences her and erases her identity. Consequently, she decides to plan a whole journey because she can't accept to be stereotyped, marginalized and othered anymore. She is in the search for this man to teach him that she is the woman.

\section{Bride: From a Flâneur to a Stalker}

Before taking any physical journey, Bride takes a voyage in. Her first voyage in becomes a site of self-discovery and marks the onset of longer physical voyage out towards self-knowledge. Where Bride is now features a drifting psychological state seeking consistency and stability. " the reason for this tracking was not love, she knew; it was more hurt than anger that made her drive into unknown territory to locate the one person she once trusted, who made her, who made her feel safe, colonized somehow (Morrison, 2015, p. 78). Contextualizing this quote within the theory developed above, what can be said is that Bride's visits to different places is not an aimless one. The journey cannot be reduced to a woman's trivial, irrational tracking of man as the God-like narrator portrays. Bride herself is aware of the fact that it is a search for trust, safety and belongingness. Bride's obsessive attitudes towards Booker's presence owe origin to the early years of her physical deprivation of mother Sweetness; the uncompassionate mother par excellence. With Booker, everything is different; what makes Bride heavily dependent on Booker's presence in her life is their ultimate connection at the physical level, unlike sweetness. Bride thinking to herself avows, "I have to stop reliving our lovemaking, I have to forget how new it felt every single time, both fresh and somehow eternal" (Morrison, 2015, p. 38).

What further proves that Bride's continuous desire to be connected physically in an obsessive way is her carriage of Booker's little things with her; when "I feel depressed the cure is 
tucked away in a little kit where his shaving equipment is" (Morrison, 2015, p. 35). Worth noting, Bride gives up on Booker's things for Rain, another traumatized character in the novel, before even meeting him realizing that their relationship is more than a physical fulfillment and her body is not hers anymore. The end of the metaphorical inward journey triggers more Bride's wish to know about herself, her man, and this ambivalent love relationship and takes her to Mr. Ponti's address. The visit to Mr. Ponti is so important because it is the first step in a hundred miles roadway. The biggest piece of the puzzle is the discovery of Booker's territory, "whisky", for realizing that she does not know him and blames herself for that "I shouldn't have--trusted him, I mean. I spilled my heart to him; he told me nothing about himself" (p. 62). Furthermore, she develops a high sense of eagerness to know more about herself. "Bride would track him, force him to explain why she didn't deserve better treatment from him, and second, what did he mean by 'not the woman?' (p. 80).

Bride's inquisitions and wondering lead her to wandering. She chooses to go to another geography, whisky, to pursue the ultimate truth. Before reaching it, she goes through an unplanned physical journey, which Morrison seems to use as a critique of the American capitalist lifestyle. The narrow curvy scary way to Whisky changes her from "a courageous adventurer into a fugitive" (my italics, Morrison, 2015, p. 83). The word 'fugitive' is highly signifyin( $g$ ). Before criticizing the capitalist-centered the American urban lifestyle, Morrison travels back in time to one of the darkest chapters in the American history and its biggest shame, the time of slavery. The whole experience of Bride moving to another place to seek emancipation can be read as an enacting of an ex- fugitive slave's attempt to scape slavery to a Free State with the help of abolitionists in the form of what was called the Underground Railroad. Long story short, Morrison proves to be a real trickster, reviving a whole history implicitly through one word.

Morrison (2015) captures the welcoming family of Evelyn and Steve and their friendly attitudes as shocking to Bride. The latter she fails to "understand the kind of care they offered-free, without judgment or a passing interest" (p.90). Her astonishment is a pointer to the fact that she has been raised up in a different culture of materialism where people do not help without a return. And more importantly, a judgmental culture that gives a great deal of attention and importance to the surface of things only. In God Help the Child, Bride's materialism is set against the hippy couple's idealism: Bride's concocted "Hollywoody, teenagery" name, reflection of her vanity, and glamorous life are in stark contrast with those of Evelyn, a true Eve" (Ramirez, 2017, p. 12). Steve strengthens the point when he asks Bride a rhetorical question "money get you out of that jaguar?" (Morrison, 2015, p. 93). Inevitably, Bride fails to grasp what Steve means because her fashionable, materialistic and superficial view of life comes up against their anti-capitalist ideals, simple and more real way of living, "a point of intersection between atomistic cultures" (Sturgeon, as cited in Ramirez, 2017, p. 12). Since every location has its own personality, the countryside's simplicity nurtures a high sense of simplicity in Bride herself.

In addition to the historical element present in Bride's slave-like journey, Morrison discloses within it a remarkable sense of antagonism towards the appropriated subject caught in the trap of the rapidly changing American urban lifestyle. Bride, as one representative of such a 
category of people, refuses to accept "the barest life" of that couple at first sight. Later on, however, Bride's encounter with a woman who does not conduct a modern life helps her free herself from the prison of pretenses she feels necessary to adopt. The comparison between the two locations and their impact on Bride's personality is pertinent; while Bride falls in the trap of shallowness in the city, she develops a deeper philosophy on life in the Evelyn's house. According to Bakhtin (2010), the idyllic chronotope generally associates to a productive growth. For Bakhtin, in such a pastoral setting, "The passage of time does not destroy or diminish but rather multiplies and increases the quantity of valuable things" (as cited in Bemong-et al., 2010, p. 207). This applies to Bride in the sense that life in a more natural geographical place brings about her growth; Bride is no longer the same.

One of the epiphanies that Bride further undergoes in the countryside is the purgation of mother Sweetness model. In contrast with mothers in the city, she learns how to shed the fact of being an appropriated mother who fails to accept the challenges and the limitations that her skin posits. Being raised up in a city, Bride could have grown into a selfish mother who neither communicates nor implants love in her child. In Evelyn's house where Bride meets Rain and learns more about pain, she gets rid of her misconceptions of what a mother could be. The experience of parenting Rain for a moment takes her to an inward journey. Bride finds within her what is missing in sweetness and Rain's mother. She learns how to reconstruct herself regardless of the harsh experiences she knows about motherhood and parenting. "Listening to this tough little girl who wasted no time on self-pity," Bride discovers that it was not all about sweetness, Bride's early dependence contributed to her own victimization (Morrison, 2015, p. 103). Such a journey can stand for a call for all the mothers to set aside the societal teachings and transcend them not through fetching somewhere so far, but just within themselves. To be able to reconstruct the outside world, cleansing the mess within is the first step to take in the journey of social reconstruction. In this vein, Johnsi (2018) contends that "At the end of the novel, Bride acquires, apparently, the sense of self-required to mother her baby and not to reproduce Sweetness. There is a ray of hope in the ending of this brisk tale" (p.175). Mothers, a very crucial section of community, need to be empowered and thus by improving Bride's sense of motherhood, Morrison improves that of many other countless mothers who have been willingly or unwillingly appropriated. In other words, Morrison incarnates the model of the m-other, who treats her child as the other, and presents it as a site of empowerment. According to Ramirez- (2015), "Morrison envisions a hopeful future in Bride's mothering as a potential site of empowerment of children in the face of racism (and sexism)" (p.12). Hence, in the countryside, Bride sheds the superficiality of the capitalist ideals and develops of better sense of motherhood.

The last station of Bride's journey is her way to self-empowerment which implies the empowerment of the black community. Whiskey, as described, has been

Half a dozen or so houses on both sides of a gravel road that led to a stretch of trailers and mobile homes. Parallel to the road beyond a stretch of sorrowful-looking trees ran a deep but narrow stream. The houses had no addresses but some mobile homes had names painted on sturdy mailboxes. (Morrison, 2015, p.142) 
The new territory matches perfectly with Bride's state of mind. She feels at odd with where the malign forces are taking her again. In addition to that, she is sorrowful like a tree at a dying summer. And just like those houses with no address, Bride does not own the discourse of her body and identity. Booker's aunt, Queen Olive, stresses the point commenting that Bride looks like "something a raccoon found and refused to eat," when first seeing her (p. 144). Queen Olive "deleted an entire vocabulary of compliments in one stroke" (p. 144). In whisky, Bride is not looked at through the ideals of the city where she is the exotic panther in snow who could impress anyone she meets. Bride's astonishment of what she has become in Olive's house raises questions about how the blacks still internalize their otherness. Bride refusal to be treated like a normal woman implies that the blacks' unconscious is still troubled by a perpetuated inferiority. Racism is injected to the subconscious mind of the black people. Morrison offers the example of Queen Olive and her story with many husbands with different culture. Queen Olive is the best character of racial flexibility. Due to her experience with marriage, she fosters the idea of plurality and accepting the other. The latter consists one of the basic principles that normally build the American culture. Historically, the land of dreams welcomed countless immigrants from different nations, races and cultures, offering equal opportunities to every one of them regardless. The beauty of the American culture lies in being a Salad pot. Bride, at this level, has to shed her sense of otherness, which is based on her skin color.

Bride's experience with Olive is not significant at a personal level only but at a communal one. Due to Queen Olive, Bride seems to embrace a new mestiza consciousness.

She sheds all masks of the rising consumerist, materialistic culture. We cannot say that she has developed a new identity; she has just gone over some of the past mistakes. Before profiting from her black beauty, she should have loved it first. The journey to Olive's house makes of Bride the pride of the blacks. This black woman grows to be a new black without a false-consciousness of being defined by or dreaming about the white men's culture. In view of that, Ramirez (2017) contends that, "Through Bride, Morrison interrogates again the dominant value system, deconstructing the prevailing notions of beauty and materialist values. She epitomizes the process of decolonization of the black female's psyche and, on the whole, African Americans' resistance to oppression"(p.13). Therefore, Bride's emancipation and empowerment stands for the black community's success to achieve freedom and be empowered.

Morrison's fiction criticizes the rising sample of the new blacks who are generally materially prosperous black people as who give a great deal of attention only to money and success but never to the ethic of love. Bride's group work with Booker in saving Olive's life proves them to be "a true couple, thinking not of themselves, but of helping somebody else" (p. 167). At this point, Bride becomes remarkably tolerant, compassionate, and caring. In so being, Bride subverts the stereotype of the new black whose "interpersonal relationships are capitalistic, exploitative and utilitarian" (Silini \& Majdoubeh, 2018, p.10).

In this journey, Booker's trailer becomes a site of rehummanization for Bride. She finally reaches the final station, Booker, the one whom meeting him feels like coming to terms with herself; with her past. After heading to the trailer and seeing him there, "Bride [runs] nine quick steps forward and slap[s] Booker's face as hard as she could" (Morrison, 2015, p. 152). Bride faces 
Booker with the amount of pain she has felt after his colonization of her with one expression "you are not the woman" (p. 8). His accusation and absence thingnified her that is why she proffers to use violence to re-humanize. In the trailer, she is no longer dependent nor colonized by her past. In the city with Sweetness she has been the stranger at home because of who she is, and in whisky she rather learns how to accept who she is regardless. Bride achieves her individuation and reaches the level of freedom that she has been looking for. "Having confessed Lula Ann's sins she felt newly born," she goes back to her first identity (my italics, p. 162). Morrison uses Bride's first name to show how at the moment Bride gets rid of the burden of appropriation by society and colonization by Booker, she recaptures the girl who has once been so helpless. Subsequently, she even notices "the return of her flawless breasts" (p.166). Bride recovers her body and thus reclaims her identity.

Morrison associates Bride's healing to nature to demonstrate how the black needs to go back to their original lifestyle (agriculture and life of nature). Nature has her own special methods of healing the bruised spirit and the torn in mind. As it has been explained throughout, Bride seems to be closer to recovery, the more she gets far from the city towards the bare nature and the anticapitalist lifestyle. In the lap of nature, Bride resets herself far from the world of the city. Historically, the blacks' mass migration goes back only to the roaring twenties when America had been growing as a strong economic power. Even if they exceled at artistic expression voicing a black identity, the city could have a negative impact on them.

Morrison utilizes elements of naturalism, transcendentalism and romanticism to subvert the growing materialism of western civilization. Bride the romantic heroine who finds herself guided by divine forces in her way to find what she has lost in spiritual realms struggles to transcend the ideologically-filled societal dictations. The bare nature lays her bare herself. Its purity does not require people holding masks. Through such an encounter with the pastoral and the different lifestyle in the countryside, Bride realizes that the surface of her power is a futile one. She is building her new self on a fragile ground; as if the anti-capitalist, barest lifestyle takes her from the peel to the gist of what life and its essence are. The contradiction awakens the black woman to the fact that she is still fighting a small battle using ineffective weapons associated with a normative culture. Such a realization is what pushes Bride to embrace more the blacks' cultural values and ideals of self-worth, pride, unity, and love, just to name a few.

\section{Conclusion}

Through the prism of psychogeography, God Help the Child attests that geography is a shaping force of the characters' psychological state. Bride metamorphoses from a flâneur to a stalker who reconstructs identity gradually through a number of voyages in/out. God Help the Child is a healing story par excellence. In it, Morrison develops a narrative replete with geographies and different settings (Decagon, the countryside, and whisky) that could impact Bride's behavior and psyche. Despite the fact that the story is not a happy one, nor the voyages are easy, it ends happily heralding a better tomorrow. The Cathartic journeys help her to know more about herself and what it means to be a black mother, to shed the mask of capitalism and more importantly to instill racial pride in black people. In so doing, she empowers the black individual that would in turn empower the entire black community.

Arab World English Journal for Translation \& Literary Studies 


\section{About the Author:}

Dr. Hana BOUGHERIRA is a full time lecturer (class B) and a head of English specialization at the English Department of Skikda University/Algeria. My doctoral research explored the discourse of empowerment in Postcolonial Literature and Literature of the Oppressed.

ID ORCid: https://orcid.org/0000-0002-8589-7616

\section{Note:}

${ }^{1}$ This is the original passage by debord which translates into... «l'étude des lois e a tes et des effets $p$ é is du ilieu géographique, consciemment aménagé ou non, agissant directement sur le comportement affectif des individus »(as cited in Muis, $p .2$ )

\section{References}

Akhtar, J. (2018). Toni Morrison and the new black reading God help the child. New York: Routledge

Bemong, N.et al. (Eds.). (2010). Bakhtin's Theory of the Literary Chronopote: Reflections, Applications, Perspectives. Gent, Belgium: Academia Press

Bougherira, H. (2017). Voicing the Silenced and Empowering Community in Selected Works of Toni Morrison, Ahlem Mostaghanemi, Chinua Achebe and Harris Wilson. University of Jordan Amman, Jordan (Doctoral Dissertation). Retrieved from http://hip.jopuls.org.jo/c/portal/layout

Coverley, M. (2006). Psychogeography: Pocket Essentials, Coleswood: Oldcastle Books.

Gras, D. (2016).Post What? Disarticulating Post-discourses in Toni Morrison's God help the child. MDP Humanities, 5 (80), 2-18. doi:10.3390/h5040080

Downing, H. (2015). Iain Sinclair and the Psychogeography of the Split City. University of London, Birkbeck, Great Britain (Doctoral Dissertation). Retrieved from https://www.semanticscholar.org/paper/Iain-Sinclair-and-the-psychogeography-of-thesplit-Downing

Gay, R. (2015). God Help the Child by Toni Morrison Review: Incredibly powerful. The Guardian. Retrieved from https://www.theguardian.com/books/2015/apr/29/god-help-thechild-toni-morrison-review-novel

Brannya, G. (2017). A Dissolution of Borderlines in Toni Morrison's God Help the Child. Sociology Study, 7(7), 364-370. doi: 10.17265/2159-5526/2017.07.002.

Johnsi, A. (2018). The Impact of Maternal Influence in Toni Morrison's God Help the Child. International Journal of Research in Business Management, 6(4), 81-88. Retrieved from http://oaji.net/articles/2017/490-1530354728.pdf

Ma, Y., \& Liu, L. (2017). Making of the Body: Childhood Trauma in Toni

Morrison's God Help the Child. Journal of Languages and Culture, 8(3) 18-23.

Retrieved from https://www.researchgate.net/publication/315944822_Making_of_the_body_Childhood_t rauma_in_Toni_Morrisons_God_Help_the_Child

Manuela, L. R. (2015). What you do to Children Matters: Toxic Motherhood in Toni Morrison's God Help the Child. Working Papers on English Studies, 22, 107-119. doi:10.17561/grove.v0i22.2700 
Manuela, L. R. (2016). Childhood cuts Festered and Never Scabbed over: Child Abuse in Toni Morrison's God Help the Child. Alicante Journal of English Studies, 29, 145-164.

Retrieved from

https://www.researchgate.net/publication/318357656_Childhood_Cuts_Festered_and_Neve

r_Scabbed_Over_Child_Abuse_in_Toni_Morrison's_God_Help_the_Child

Manuela, L. R. (2017). Racialized Beauty: The Ugly Duckling in Toni Morrison's God

Help the Child. Complutense Journal of English Studies, 173-189.

https://revistas.ucm.es/index.php/CJES/article/view/55255/52476

Marshalls. (2018, February 27). An Introduction to Psychogeography.[Blog post]. Retrieved from https://www.marshalls.co.uk/commercial/blog/an-introduction-topsychogeography.

Morrison, T. (2015). God Help the Child. Alfred A Knopf.

Myra, I. (2018). Comparative Analysis of 'Beloved' and 'God Help the Child' by Toni Morrison. International Journal of Scientific and Research Publications, 8(9), 560-567. doi: 10.29322/IJSRP.8.9.

Paula, M. S. (2018). The Secret of Bride's body in Toni Morrison's God Help the Child. Critique Studies in Contemporary Fiction, 59(1), 609-623. doi: 10.1080/00111619.2018.1470080

Richardson, T. (ed.). (2015). Walking inside out: Contemporary British Psychogeography. London: Rowman and Littlefiled.

Sahar, A., Asad, M., \& Kifah O. (2017). A Postcolonial Approach to the Problem of Subalternity in Toni Morrison's God Help the Child. International Journal of Applied Linguistics and English Literature, 7 (1) 177-183. Retrieved from https://www.researchgate.net/publication/321834587_A_Postcolonial_Approach_to_the_Pr oblem_of_Subalternity_in_Toni_Morrison's_God_Help_the_Child

Silini, R., \& Majdoubeh, A. (2018). Space and the Commodification of Difference in Toni Morrison's God Help the Child. Jordan Journal of Modern Languages and Literature, 10(1), 77-93. Retrieved from https://www.researchgate.net/publication/331180921_Space_and_the_commodification_of _difference_in_Toni_Morrison's_God_Help_the_Child

Stein F. H. (Ed). (1989). Maps from the Mind: Readings in Psychogeography. Oklahoma, United States: University of Oklahoma Pres 